Profesor dr Milojko Jevtović, dipl. inž. Elektrotehnički fakultet, Banja Luka

\section{ARHITEKTURA KVALITETA USLUGA TELEKOMUNIKACIONIH MREŽA}

UDC: 621.39

Rezime:

U radu je analizirana arhitektura kvaliteta usluga (Quality of Service, QoS) s ciljem da se definišu kriterijumi združivanja protokola kvaliteta usluga prema različitim klasama usluga (Class of Service, CoS) telekomunikacione mreže. Na osnovu definisanih klasa usluga, tipa mreže i primenjenih tehnika prenosa signala, mogu se definisati arhitekture QoS protokola koje zadovoljavaju zahtevane nivoe QoS-a za različite CoS, posebno za one koje zahtevaju komunikaciju u realnom vremenu.

Ključne reči: kvalitet usluga, arhitekture kvaliteta, telekomunikacione mreže, analiza arhitektura, kriterijumi pri projektovanju.

\title{
QUALITY OF SERVICE ARCHITECTURES IN TELECOMMUNICATION NETWORKS
}

Summary:

This paper examines the problem of quality of service architectures implementation in today's telecommunication networks. The analyses of $Q o S$ architectures are given with particular emphasis on the criteria for QoS protocol embedding. According to predefined QoSs, types of network and techniques for signal transport, it is posible to determine QoS protocol architectures which will satisfy required QoS levels.

Key words: quality of service, QoS architectures, telecommunication networks, analysis of architectures, design criteria.

\section{Uvod}

Standardne paketske računarske mreže zasnovane na IP protokolu (Internet Protocol), po svojoj tehničkoj koncepciji pružaju „,best effort“ kvalitet usluga (Quality of Service, QoS) pri prenosu podataka. Drugim rečima, obezbeđuju samo onaj nivo kvaliteta koji mreža u određenom trenutku može dati, a ne obezbeđuju zahtevani niti garantovani kvalitet usluga. Takve mreže, kao što je globalna računarska mreža Internet, prenose pakete sa kašnjenjem, varijacijom kašnjenja i određenom verovatnoćom gubitka paketa podataka. Ovakav kvalitet zadovoljava samo tipične
Internet aplikacije, odnosno klase usluga (Class of Service, CoS), kao što su:

- elektronska pošta (e-mail);

- prenos datoteka (file transfer);

- Web aplikacije (WWW applications)

Kašnjenje pri prenosu paketa preko IP mreže stvara velike probleme za aplikacije koje zahtevaju prenos u realnom vremenu, kao što su: multimedijalna komunikacija, video konferencije i paketski prenos govora. Čak i na relativno neopterećenim IP mrežama kašnjenje pri isporuci paketa poruke vrlo je veliko i ne može se jednostavno prilagoditi za komunikaciju u realnom vremenu. 
Da bi se obezbedile nove klase usluga i komunikacija u realnom vremenu, IP mreže se moraju dopuniti novim tehničkim rešenjima, tj. kvantitavnim i kvalitativnim performansama. To zahteva da se IP mreži doda određeni nivo ,inteligencije“, kako bi bio podržan saobraćaj koji zahteva stroga vremenska ograničenja u prenosu kroz datu mrežu. Pri tome se imaju u vidu zahtevi za: širinu propusnog opsega, ograničeno kašnjenje, džiter i verovatnoću gubitka paketa. Problem se rešava korišćenjem određenih QoS protokola.

Da bi se mreža prilagodila potrebama tih različitih tipova QoS-a, razvijeni su i koriste se brojni različiti QoS protokoli i algoritmi, među kojima se najčešće primenjuju:

- protokol integrisane usluge - IntServ protokol (Integrated Service), dodelom prioriteta, koji vrši selekciju saobraćajnih tokova pri obezbeđenju kvaliteta usluga;

- Subnet Bandwidth Management, SBM protokol, koji omogućava kategorizaciju i prioritete paketa podataka na drugom sloju (Layer 2), odnosno na vodu podataka OSI modela mreže, deljenjem i komutacijom mreže prema standardu IEEE 802;

- ReSerVation Protocol (RSVP), koji obezbeđuje signalizaciju da bi omogućio rezervaciju mrežnih resursa (postupak poznat kao integrisane usluge, engl. Integrated Service);

- Differentiated Services (DiffServ), koji predstavlja jednostavan način za kategorizaciju i obezbeđenje prioriteta tokova mrežnog saobraćaja;

- protokol prenosa u realnom vremenu RTP (Real Time Protocol, RTP), koji obezbeđuje sinhronizaciju paketa na odredištu i prenos podataka u realnom vremenu;

- protokol upravljanja u realnom vremenu RTCP (Real Time Control Protocol), koji obezbeđuje informacije o kvalitetu prenosa poruka, identifikuje RTP izvor, obavlja nadzor saobraćaja u mreži, itd.;

- protokol komutacije multiprotokolske labele MPLS (MultiProtocol Label Switching) koji je namenjen za označavanje, rutiranje, usmeravanje i komutaciju saobraćaja, a omogućava upravljanje propusnim opsegom za skupove saobraćajnih tokova preko mreže sa rutiranjem i usmeravanjem saobraćaja koji je upravljan labelom. MPLS je više protokol „,inžinjeringa saobraćaja“, nego što je protokol kvaliteta usluga.

Pored pomenutih, u protokole kvaliteta usluga ubrajaju se: protokoli ATM adaptacionog sloja AAL-1, AAL-2 i AAL-5, Internet protokol verzije 6 (IP v6), multiprotokolska komunikacija preko ATM mreže - MPOA, protokoli virtuelnih privatnih mreža (VPN), npr. protokol PPTP.

\section{Hijerarhije i arhitekture QoS telekomunikacionih mreža}

Multimedijalni informacioni sistemi formiraju se nad slojevitom strukturom različitih telekomunikacionih mreža koje se mogu predstaviti određenom hijerarhijskom strukturom, kao što je prikazano na slici 1.

Svaka od mreža u prikazanoj hijerarhijskoj strukturi obezbeđuje sopstveni mrežni QoS [1]. Najniži u hijerarhiji su optički, tj. talasni multipleksni sistemi (Wave Division Multiplex, WDM ili DWDM), 


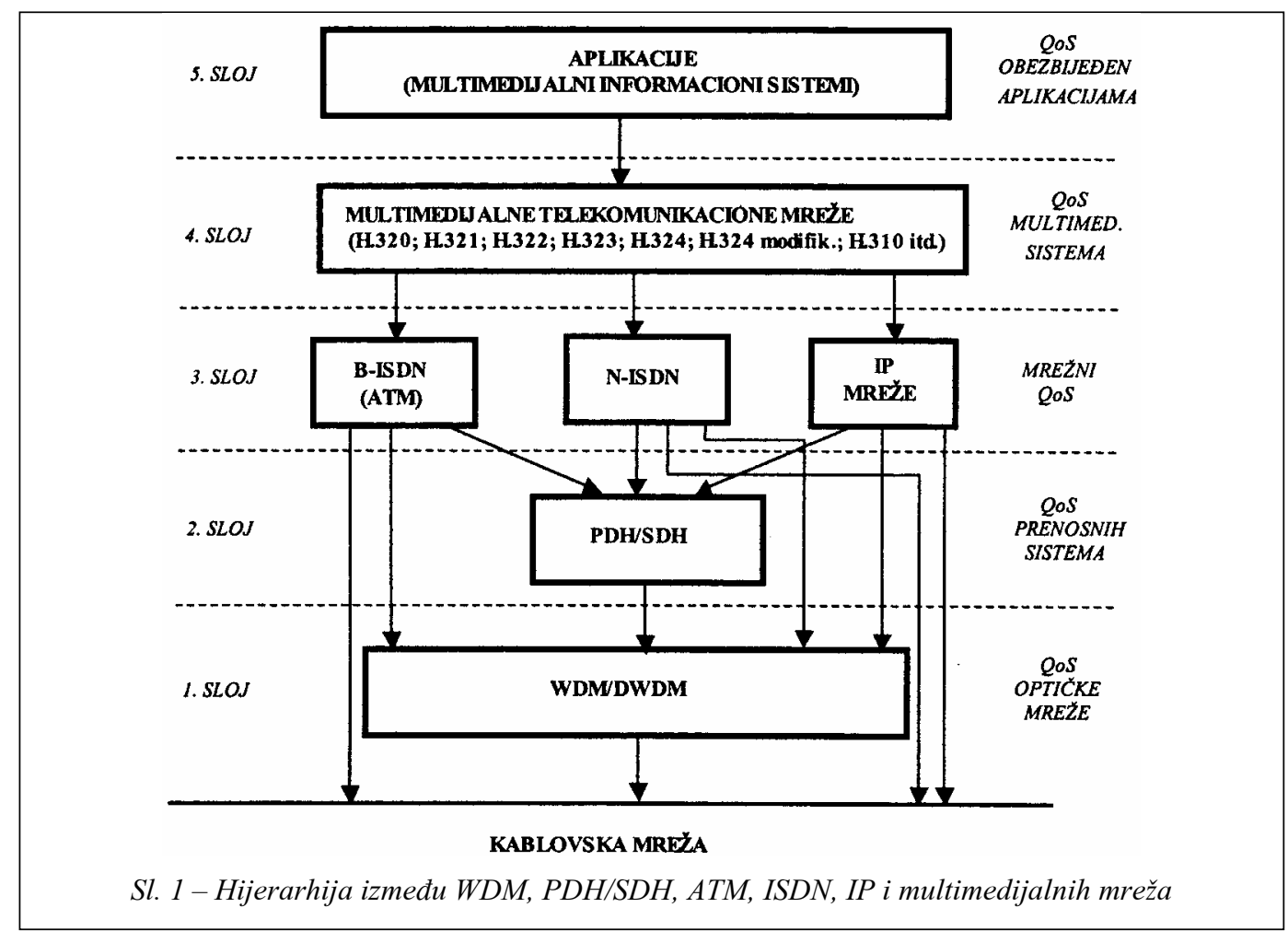

odnosno optička kablovska mreža sa talasnim multipleksnim sistemima.

$\mathrm{Na}$ drugom sloju, nad WDM optičkom mrežom nadgrađuje se mreža pleziohronih, odnosno sinhronih digitalnih hijerarhijskih prenosnih sistema, tj. kombinovanih PDH/SDH sistema (Plesiochronous Digital Hierarchy/Synchronous Digital Hierarchy).

$\mathrm{Na}$ trećem sloju, odnosno nad $\mathrm{PDH} / \mathrm{SDH}$ mrežom, formiraju se digitalne mreže integrisanih službi: uskopojasna ISDN (Integrated Service Digital Network) mreža (N-ISDN) ili širokopojasna ATM (Asynchronous Transfer Mode) mreža (B-ISDN). Na istom sloju, iznad PDH/SDH može biti formirana paketska IP mreža ili MPLS mreža.

$\mathrm{Na}$ četvrtom sloju arhitekture mreža formiraju se, odnosno nadgrađuju multime- dijalne mreže prema standardima: H.320, H.323, H.324, H.321, H.311 Međunarodne unije za telekomunikacije (ITU-T).

Peti sloj u hijerarhiji čine razne aplikacije, odnosno multimedijalni informacioni sistemi, kao što su: telemedicina, rad na daljini, obrazovanje na daljini, elektronska trgovina (e-commerce), elektronsko bankarstvo (e-banking), elektronsko poslovanje, meteorološki informacioni sistemi, vojni komandno-informacioni sistemi i dr.

\section{OSI arhitektura protokola kvaliteta usluga}

QoS pojedinih mreža u prikazanoj hijerarhiji, pored ostalog, podržava skup protokola kvaliteta usluga. Uobičajeno je da su ti QoS protokoli pridruženi OSI ar- 
hitekturi komunikacionih protokola date mreže. Jedan primer OSI arhitekture mreža sa pridruženim QoS protokolima prikazan je u tabeli 1.

\section{Združivanje QoS protokola}

Svaki od navedenih tipova protokola QoS-a može se nezavisno koristiti s kraja na kraj veze, odnosno u komunikaciji od predajnika do prijemnika. U realnim primenama ne dešava se da se pojedinačni QoS protokoli koriste nezavisno, već se kombinuju sa drugim tipovima protokola.

Protokoli su projektovani tako da se mogu koristiti sa drugim QoS tehnikama primenjenim između predajnika i prijemnika, a obezbeđuju kvalitet usluga ,od vrha do dna" (top-to-bottom), odnosno odozgo nadole i ,s kraja na kraj veze“ (endto-end). Na slici 2 prikazana je arhitektura nekoliko združenih QoS protokola.

DiffServ je komplementaran protokolu RSVP, a zajedno ovi protokoli obezbeđuju QoS s kraja na kraj veze. Krajnji računari mogu koristiti RSVP zahteve sa zadatim parametrima QoS-a (propusni opseg, kašnjenje, džiter, itd.). Granični ruteri na ulaznim tačkama kič- mene mreže (Backbone network) preslikavaju RSVP „rezervaciju“ na klase usluga polja TOS (Type Of Service) protokola IP v4, odnosno na DS bajt (polje TOS) u zaglavlju ovog protokola. Na izlazu kičmene mreže ponovo se obezbeđuje RVSP, odnosno rezervacija resursa do krajnjeg odredišta. Na sličan način kombinuje se protokol RSVP u lokalnoj računarskoj mreži (LAN) sa MPLS protokolom u kičmenoj WAN mreži.

Jedan primer združivanja QoS protokola predstavlja skup protokola koji podržavaju paketski prenos govora u IP mrežama, odnosno VoIP. Na slici 3 prikazan je postupak formiranja zaglavlja paketa govornog signala, korišćenjem RTP, UDP i IP v4 protokola.

Govorni signal se konvertuje u digitalni oblik i komprimuje u pakete ili datagrame, primenom algoritma kompresije koji je definisan ITU-T standardom G.723.1. Ramovi - paketi su trajanja 30 ms, pri čemu svaki ram sadrži 24 bajta. Bitski protok je 6,4 kb/s. Na svaki ram datagram ili paket govornog signala dužine 24 bajta dodaju se zaglavlja protokola IP, UDP i RTP. Formira se zaglavlje dužine 40 bajta na svaki informacioni ram govornog signala i dobija bitski niz protoka

OSI arhitektura sa pridruženim QoS protokolima

Tabela 1

\begin{tabular}{|l|l|c|}
\hline \multicolumn{1}{|c|}{ OSI slojevi } & \multicolumn{1}{|c|}{ QoS protokoli } & $\begin{array}{c}\text { Oznaka } \\
\text { sloja }\end{array}$ \\
\hline $\begin{array}{l}\text { Sloj primene } \\
\text { (aplikacije) }\end{array}$ & QoS koji omogućuju aplikacije & 7. sloj \\
\hline $\begin{array}{l}\text { Sloj prikaza } \\
\text { (prezentacije) }\end{array}$ & $\begin{array}{l}\text { G.711; G.722; G.728; G.723.1; G.729; M PEG-1; M PEG-2; M PEG-4; } \\
\text { JPEG, JPEG-2000; H.261; H.263; H.263. ver.3; H.320; H.321; H.322; }\end{array}$ & 6. sloj \\
\cline { 2 - 4 } Sloj sesije (dijaloga) $)$ & H.323; H.324; H.324 modifik.; H.310; H.311; T.120 (T.120-T.127) & 5. sloj \\
\hline Sloj prenosa & RSVP; RTP; RTCP; MPOA; MPLS & 4. sloj \\
\hline Sloj mreže & AAL-1; AAL-2; AAL-5; M PLS; DiffServ; IPv6; IntServ; ATM & 3. sloj \\
\hline Sloj voda podataka & ATM; SBM; M PLS; VPN (PPTP) & 2. sloj \\
\hline Fizički sloj & IEEE 802.1.Q; IEEE 802.1p; I.350; G.821; G.826 & 1. sloj \\
\hline
\end{tabular}



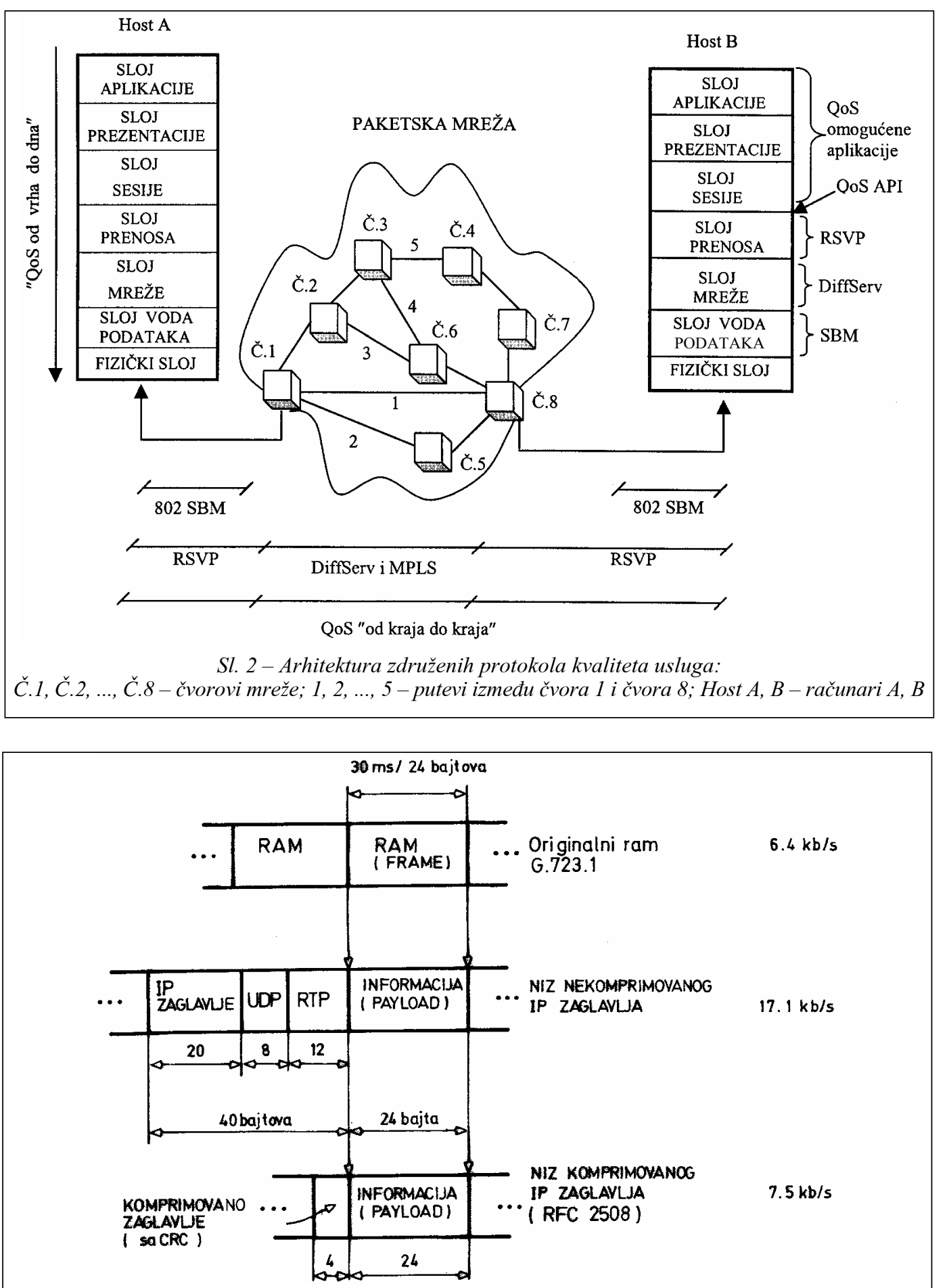

Sl. 3 - Formatiranje IP datagrama govornog signala 
$17,1 \mathrm{~kb} / \mathrm{s}$. Sledi kompresija zaglavlja prema standardu RFC 2508 i dobija digitalni signal bitskog protoka $7,5 \mathrm{~kb} / \mathrm{s}$. U ovom slučaju primenjena su dva protokola kvaliteta usluga: DiffServ (korišćenjem polja TOS u zaglavlju IP v4) i RTP protokol, koji podržava komunikaciju u realnom vremenu i sinhronizaciju paketa govornog signala.

\section{Arhitektura kvaliteta usluga multimedijalnih mreža}

Multimedijalna komunikacija može se realizovati preko različitih telekomunikacionih mreža, njihovom „nadgradnjom" u skladu sa odgovarajućim standardima. U tabeli 2 prikazan je pregled

Pregled telekomunikacionih i računarskih mreža i standarda za multimedijalnu komunikaciju i video konferencijske sisteme

\begin{tabular}{|c|c|c|c|c|c|}
\hline Standardi & Funkcija mreže & Mreža & Video & Govor & Podaci \\
\hline H.320 & $\begin{array}{l}\text { Videokomunikacija preko } \\
\text { ISDN mreže }\end{array}$ & ISDN & $\begin{array}{l}\text { H.261 } \\
\text { H.263 }\end{array}$ & $\begin{array}{l}\text { G.711 } \\
\text { G.722 } \\
\text { G.728 }\end{array}$ & T.120 \\
\hline Н.323 & $\begin{array}{l}\text { Videokomunikacija preko } \\
\text { IP/TCP računarskih mreža }\end{array}$ & $\begin{array}{l}\text { IP/TCP } \\
\text { LAN }\end{array}$ & $\begin{array}{l}\text { H.261 } \\
\text { H.263 }\end{array}$ & $\begin{array}{l}\text { G.711 } \\
\text { G.722 } \\
\text { G.728 } \\
\text { G.723.1 }\end{array}$ & T.120 \\
\hline H.324 & $\begin{array}{l}\text { Videokomunikacija preko } \\
\text { javne komutirane } \\
\text { telefonske mreže }\end{array}$ & $\begin{array}{l}\text { PSTN } \\
\text { ISDN }\end{array}$ & $\begin{array}{l}\text { H.261 } \\
\text { H.263 }\end{array}$ & $\begin{array}{l}\text { G.723.1 } \\
\text { G.711 } \\
\text { G.722 } \\
\text { G.728 } \\
7.729 \\
\text { MPEG-1 }\end{array}$ & T.120 \\
\hline Н.310 & $\begin{array}{c}\text { Videokomunikacija preko } \\
\text { ATM (prenos preko } \\
\text { B-ISDN) }\end{array}$ & $\begin{array}{l}\text { ATM } \\
\text { Cell } \\
\text { Relay }\end{array}$ & $\begin{array}{l}\text { MPEG-2 } \\
\text { H.261 }\end{array}$ & $\begin{array}{l}\text { MPEG-2 } \\
\text { G.711 } \\
\text { G.722 } \\
\text { G.728 }\end{array}$ & T.120 \\
\hline H.321 & $\begin{array}{c}\text { Videokomunikacija preko } \\
\text { ATM standarda zasnovan } \\
\text { na H.320 }\end{array}$ & ATM & $\begin{array}{l}\text { H.261 } \\
\text { H.263 }\end{array}$ & $\begin{array}{l}\text { G.711 } \\
\text { G.722 } \\
\text { G.728 } \\
\end{array}$ & T.120 \\
\hline H.322 & $\begin{array}{c}\text { Videokomunikacija preko } \\
\text { mreža sa komutacijom } \\
\text { paketa }\end{array}$ & $\begin{array}{l}\text { Frame } \\
\text { Relay }\end{array}$ & $\begin{array}{l}\text { H.261 } \\
\text { H.263 }\end{array}$ & $\begin{array}{l}\text { G.711 } \\
\text { G.722 } \\
\text { G.728 } \\
\text { G.723.1 }\end{array}$ & T.120 \\
\hline $\begin{array}{l}\text { H.324 } \\
\text { Modif. }\end{array}$ & $\begin{array}{l}\text { Videokomunikacija preko } \\
\text { mobilnih mreža }\end{array}$ & $\begin{array}{c}\text { GSM } \\
(2,5 \mathrm{G}) \\
\text { UMTS }(3 \mathrm{G}) \\
\end{array}$ & $\begin{array}{c}\text { H.261 } \\
\text { H.261 } \\
\text { MPEG-4 } \\
\end{array}$ & $\begin{array}{l}\text { G.723.1 } \\
\text { G.728 }\end{array}$ & $\begin{array}{l}\text { WAP } \\
\text { T.120 }\end{array}$ \\
\hline
\end{tabular}

Značenje skraćenica:

ISDN - Integrated Service Digital Network (digitalna mreža integrisanih službi),

PSTN - Public Switching Telephone Network (javna komutirana telefonska mreža),

LAN - Local Area Network (lokalna računarska mreža),

ATM - Asynchronous Transfer Mode (asinhroni način transfera),

GSM - Global Mobile System (globalni mobilni telefonski sistem),

UMTS - Universal Mobile Telecommunications System (univerzalni mobilni telekomunikacioni sistem),

WAP - Wireless Access Protocol (bežični protokol pristupa),

H.320, H.323, H.324, H.310, H.322, H.321, H.324.mod - Skupovi protokola Međunarodne unije za telekomunikacije, koji se odnose na videokonferencijske sisteme i multimedijalnu komunikaciju,

H.261, H.263, MPEG-2, MPEG-4 - Standardi za kompresiju/dekompresiju video slike,

G.711, G.722, G.728, G.729, G.723.1 - Standardi Međunarodne unije za telekomunikacije, koji se odnose na kompresiju/dekompresiju audio i govornih signala,

T.120 - Skup protokola Međunarodne unije za telekomunikacije, koji se odnose na prenos podataka prilikom multimedijalne komunikacije. 
telekomunikacionih i računarskih mreža i standarda za multimedijalnu komunikaciju i videokonferencijske sisteme.

Za sve navedene mreže potrebno je da se arhitekturom protokola obezbedi neophodan kvalitet usluga. Arhitekture QoS protokola nisu standardizovane.

Kao rezultat nastojanja da se obezbedi arhitektura za QoS upravljanje ,S kraja na kraj“" veze, integrisana sa mrežnokonfigurisanim QoS službama, odnosno uslugama i protokolima, predloženo je nekoliko različitih modela [5]:

- Extended Integrated Reference Model (XRM), razvijen na Columbia Univerzitetu;

- Quality of Service Architecture (QoS-A), razvijen na Lancaster Univerzitetu;

- OSI QoS Framework, koji je predložila ISO SC21 QoS radna grupa;

- Heidelberg QoS Model, koji je razvio IBM-ov evropski mrežni centar;
- OMEGA Architecture, koja je razvijena na Pennsylvania Univerzitetu;

- TINA QoS Framework, koji je razvio TINA Konzorcijum;

- IETF QoS Manager (QM), koji je razvio IETF radne grupe za integrisane službe net Architecture na California Univerzitetu;

- End System QoS Framework, koji je razvijen na Washington Univerzitetu.

$\mathrm{Za}$ detaljniju analizu interesantne su tri arhitekture QoS-a: XRM, Lancaster i OSI.

\section{XRM model}

COMET grupa, na Columbia Univerzitetu, razvila je XRM (Extended Integrated Reference Model) model kao okvir za upravljanje i nadzor multimedijalnih telekomunikacionih mreža. Ovaj model podeljen je u pet funkcionalnih ravni, sa sledećim funkcijama (slika 4):

- funkcije upravljanja, objedinjene su unutar ravni upravljanja mrežom $(\mathrm{N}$ -

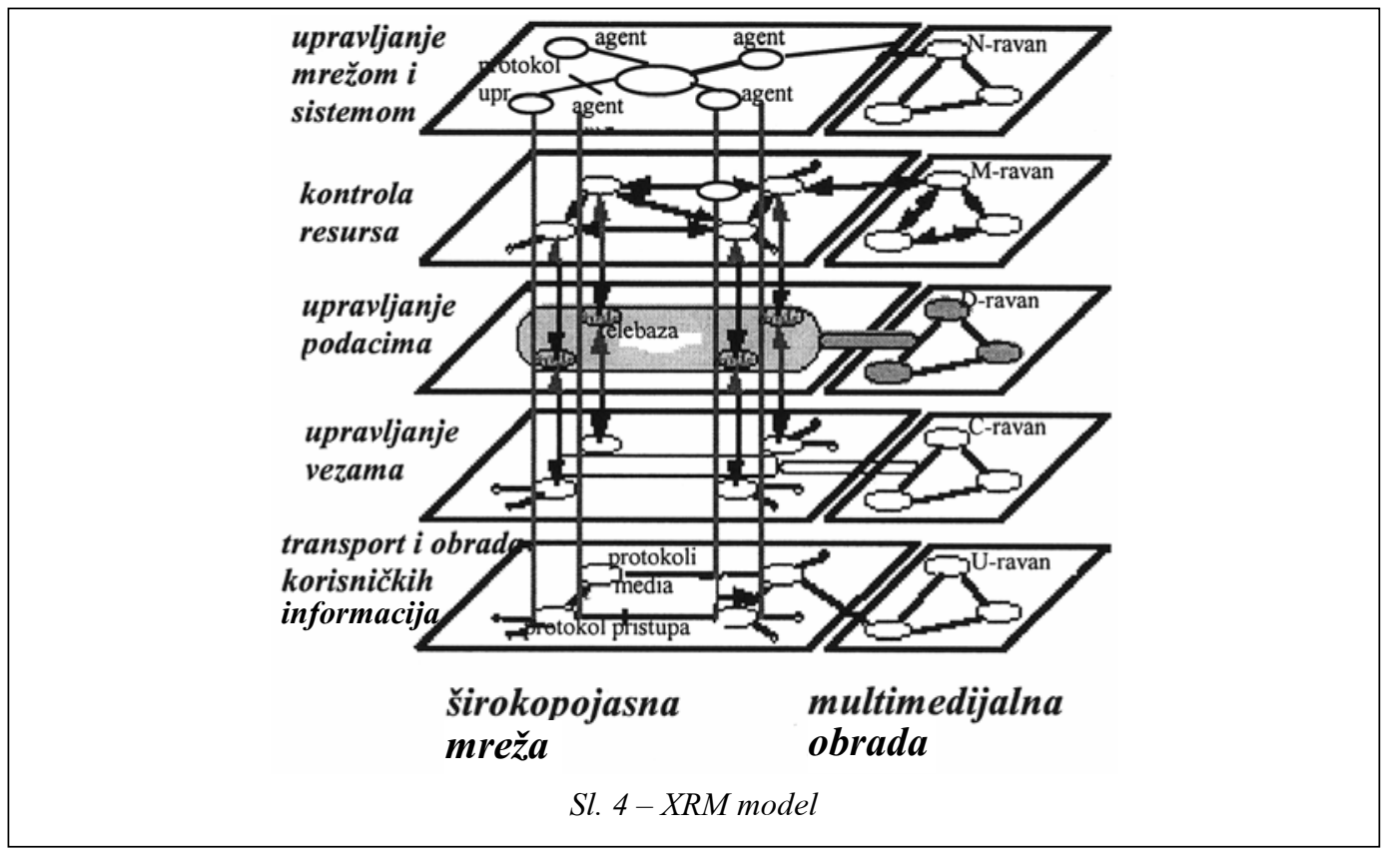


ravan) i obuhvataju OSI (Open Systems Interconnection) funkcionalna područja mrežnog i sistemskog upravljanja;

- funkcije kontrole saobraćaja, objedinjavaju kontrolu resursa (M-ravan) i kontrolnu ravan (C-ravan);

- funkcije transporta informacija, locirane su unutar korisničke transportne ravni (U-ravan) i modeliraju protokole medija i entitete za transport korisničkih informacija u mreži i krajnjim sistemima;

- telebaza, pripada tzv. D-ravni i omogućava združeno predstavljanje informacija, podataka, kao i odgovarajućih apstrakcija u postojećim mrežama i krajnjim sistemima.

XRM modelira arhitekturu ,s kraja na kraj“" kao multiprocesorsku multimedijalnu radnu stanicu čiji su osnovni elementi:

- audio i video jedinica, koja obavlja multimedijalno procesiranje;

- ulazno-izlazni podsistem,

- jedinica glavnog procesora.

QoS za određene klase usluga definisan je preko skupa parametara (kašnjenje, gubici, džiter, itd.). Metodologija karakterizacije mrežnih resursa proširena je na krajnji sistem radi definisanja kapaciteta multimedijalnih uređaja.

\section{Lancaster QoS arhitektura}

QoS arhitektura (QoS-A) jeste slojevita arhitektura za opis službi i mehanizama QoS upravljanja, kao i kontrole prenosa multimedijalnog saobraćaja (slika 5).

Sloj distribuirane sistemske platforme obezbeđuje multimedijalnu komunikaciju i realizovanje željenog QoS-a u objektivnoorijentisanom okruženju. Sloj konfiguracije i sinhronizacije obavlja ko- rekciju džitera i multimedijalnu sinhronizaciju, dok transportni sloj sadrži skup QoS konfigurabilnih službi i mehanizama. Niži slojevi predstavljaju osnovu za QoS podršku ,s kraja na kraj“.

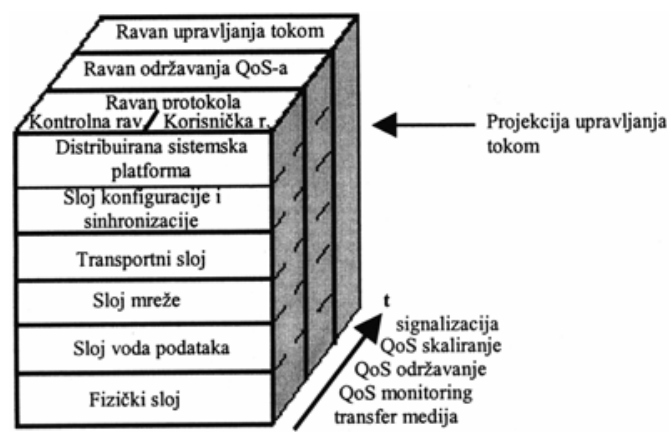

Sl. 5 - QoS-A model

QoS upravljanje se realizuje $\mathrm{u}$ tri vertikalne ravni. Ravan protokola, koju čine korisničke i kontrolna podravan, zasnovana je na principu korišćenja odvojenih profila zbog različitih QoS zahteva za upravljanje i prenos. Ravan održavanja QoS-a sadrži mehanizme za nadzor i održavanje pridruženih entiteta protokola. Ravan upravljanja tokom obezbeđuje funkcije kontrole pristupa „s kraja na kraj", QoS bazirano rutiranje i rezervaciju resursa, QoS mapiranje (translacija QoS reprezentacije između slojeva) i QoS skaliranje (obuhvata QoS filtriranje i adaptaciju).

\section{OSI QoS arhitektura}

OSI radni model predstavlja okvir za definisanje QoS terminologije i koncepta, a prvenstveno omogućava identifikaciju objekata koji su od interesa za QoS u standardima za otvorene sisteme. QoS objekti i njihove interakcije opisuju se definisanjem skupa QoS karakteristika. Osnovni elementi ovog koncepta su: 
- QoS zahtevi, koji se realizuju preko entiteta QoS upravljanja i održavanja;

- QoS karakteristike, koje predstavljaju opis osnovnih QoS merenja koje je potrebno obaviti;

- QoS kategorije, koje obuhvataju grupe QoS zahteva koji se odnose na pojedinačna okruženja (npr. vremenski kritične komunikacije);

- QoS funkcije upravljanja, koje se mogu primeniti na različite QoS karakteristike kako bi se ispunili određeni QoS zahtevi.

\section{Zaključak}

Obezbeđenje QoS-a u savremenim telekomunikacionim mrežama predstavlja jedan od dominantnih zahteva pri planiranju i projektovanju mreže. Primena poboljšanih tehnologija digitalne obrade signala i algoritama kompresije govora daje optimalne rezultate samo uz implementaciju efikasnog mehanizma (protokola, algoritma) za realizovanje željenog QoS-a. Pri tome, funkcionisanje ovakvog mehanizma mora biti nezavisno od načina implementacije osnovne mrežne infrastrukture (ATM, IP, Frame Relay, ISDN, itd.).

Arhitekture QoS-a analizirane $\mathrm{u}$ ovom radu, zasnovane su na slojevitoj strukturi koja je preduslov za obezbeđenje kvaliteta usluga „od vrha do dna“ (top-to-bottom) i „s kraja na kraj veze“ (end-to-end).

Literatura:

[1] Jevtović, M:: Kvalitet usluga telekomunikacionih mreža, IBSN 86-903281-1-4, Grafo-Žig, Beograd, str. 228, 2002.

[2] Jevtović, M.: Protokoli kvaliteta usluga, Telekomunikacije, No 2, 2003.

[3] Jevtović, M., Gardašević, G.: Analiza protokola kvaliteta usluga, Zbornik Konferencije ETRAN-a, Igalo, jun 2003.

[4] QoS protocols \& architectures, White Paper, qosport_v.3.doc, www.stardust.com, qosport v.3.doc, July 1999.

[5] Campbeli, A.; Aurrecoeches, C.; Hauw L.: A Review of QoS Architectures, ACM Multimedia Systems Journal, 1996. 
